\title{
Pengaruh Model Pembelajaran Inkuiri dengan Menggunakan Media Simulasi Terhadap Hasil Belajar Fisika Siswa Kelas X MIA SMAN 1 Lingsar Lombok Barat Tahun Pelajaran 2016/2017
}

\author{
Suci Nujul Hayati, Hikmawati, Wahyudi \\ Program Studi Pendidikan Fisika \\ Universitas Mataram \\ Mataram, Indonesia \\ Email: sucinujulhayati@gmail.com
}

\begin{abstract}
Abstrak - This study aims to determine the effect of inquiry learning model using simulated media on learning outcomes physics class X SMAN 1 Lingsar Lombok Barat in the academic year 2016/2017. This kind of research is quasi experimental research design posttest control group design. Population of this research is all students in grade X SMAN 1 Lingsar the school year 2016/2017. Sample was taken by purposive sampling technique, in order to obtain class X mathematics and natural sciences 2 consisting of 25 students as an experimental class and class X mathematics and natural sciences 3 consisting of 24 students as the control class. Instruments in the form of multiple choice questions test which refers to the students' cognitive abilities as many as 30 items with due regard to the validity, reliability, power and the level of difficulty depending matter. Based on the results obtained that the average value of 68,4 posttest experimental class and control class 58,75. Data obtained in advance were tested for normality and homogeneity, earned both classed of normally distributed and homogeneous. Research hypotheses were tested using $t$-test polled variance, obtained $t_{\text {count }}$ and $t_{\text {table }}$ by 2,98 and 2,01 at the 5\% significance level. Therefore $t_{\text {count }}>t_{\text {table }}$ then $H_{0}$ is rejected and $H_{a}$ accepted. So, it can be concluded that there are significant inqury learning model using simulated media on learning outcomes physics class X SMAN 1 Lingsar Lombok Barat lessons year 2016/2017.
\end{abstract}

\section{Keywords : Inquiry learning, media simulation, student learning outcomes}

\section{Pendahuluan}

Sekolah, guru dan siswa memegang peranan penting dalam proses pembelajaran. Dalam proses pembelajaran senantiasa terjadi kegiatan interaksi antara dua unsur manusia yaitu siswa sebagai pihak yang belajar dan guru sebagai pihak yang mengajar. Peran kolaboratif antara siswa dengan guru sangat dibutuhkan demi terciptanya pembelajaran yang interaktif dan inovatif.

Menurut Straits dan Wilke model pembelajaran inkuiri merupakan salah satu model pembelajaran yang berperan penting dalam membangun paradigma pembelajaran konstruktivistik yang menekankan pada keaktifan belajar peserta didik (Jufri, 2010). Model dan media pembelajaran yang digunakan akan menentukan situasi selama berlangsungnya proses kegiatan pembelajaran. Oleh karena itu, guru dituntut untuk dapat kreatif memilih model dan media mana yang paling sesuai untuk diterapkan dalam suatu kelas (Rusman, 2013).

Berdasarkan hasil observasi yang dilakukan di SMA Negeri 1 Lingsar yang menerapkan Kurikulum 2013 pada kelas X, nilai ulangan harian fisika masih banyak di bawah Kriteria Ketuntasan Minimum (KKM).
Tabel 1. Nilai Rata-rata Ulangan harian Mata Pelajaran Fisika Tahun Pelajaran 2016/2017

\begin{tabular}{cccc}
\hline No & Kelas & Nilai Rata-Rata & Jumlah Siswa \\
\hline 1 & X MIA 1 & 59,87 & 25 \\
2 & X MIA 2 & 53,94 & 25 \\
3 & X MIA 3 & 55,35 & 24 \\
4 & X MIA 4 & 56,79 & 27 \\
\hline
\end{tabular}

Hal ini disebabkan antara lain karena guru masih menerapkan pembelajaran yang berpusat pada guru (teacher centered learning), dan media yang digunakan guru tidak bervariasi. Akibatnya siswa kurang memahami konsep-konsep fisika, merasa bosan dan acuh untuk belajar fisika, sehingga hasil belajarnya kurang memuaskan.

Salah satu model dan media yang dapat mengaktifkan dan meningkatkan motivasi siswa adalah model pembelajaran inkuiri dengan menggunakan media simulasi. Dimana dalam model pembelajaran inkuiri dengan menggunakan media simulasi, siswa dapat terlibat secara langsung untuk memecahkan permasalahan melalui tugas yang diberikan oleh guru, baik secara berkelompok maupun 
individual. Dalam proses pembelajaran di sekolah tersebut pada mata pelajaran fisika, media simulasi ini belum pernah digunakan, untuk menggantikan peran dari alat-alat peraga, sehingga merupakan hal yang baru dan menarik bagi siswa.

Beberapa penelitian sebelumnya menunjukkan sejumlah pengaruh penggunaan model pembelajaran inkuiri dalam pembelajaran di kelas. Hal ini sesuai dengan penelitian bahwa model pembelajaran inkuiri dengan menggunakan media simulasi mengalami peningkatan hasil pada aktivitas siswa dan hasil belajarnya. hasil belajar aspek kognitif siswa yang diperoleh siswa yaitu 68,97 dan rata-rata nilai aktivitas belajar yang diperoleh siswa sebesar 73, 90 pada kelas kontrol, sedangkan pada kelas eksperimen diperoleh hasil belajar aspek kognitif sebesar 77,32 dan rata-rata nilai aktivitas belajar yang diperoleh siswa sebesar 83,51 (Yulian et al, 2015).

Hasil belajar kognitif siswa mengalami peningkatan nilai rata-rata serta terpenuhinya ketuntasan belajar siswa setelah diterapkannya model pembelajaran inkuiri terbimbing pada pokok bahasan cahaya dikelas eksperimen. Hasil yang diperoleh yaitu pada kelas ekpserimen nilai rata-rata sebelumnya 51,84 menjadi 75,85 dean ketuntasan belajar siswa juga meningkat dari $28,57 \%$ meningkat menjadi $85,71 \%$ (Wijayatni et al, 2010).

Hasil bahwa model inkuiri terbimbing dapat meningkatkan minat dan hasil belajar siswa di SMAN 14 Semarang yakni siswa yang mencapai ketuntasan meningkat dari 13 siswa menjadi 38 siswa dan tanggapan siswa sebelum tindakan sebesar $72,90 \%$ dan setelah tindakan meningkat menjadi 76, 81\% (Isa et al, 2010).

\section{Tinjauan Pustaka}

\section{A. Model Pembelajaran Inkuiri}

Model pembelajaran adalah model yang bisa dijadikan sebagai pola pilihan yang berarti bahwa para guru bebas memilih model-model pembelajaran dalam melaksanakan pembelajaran di kelas untuk mencapai tujuan pendidikan (Rusman, 2010). Inkuiri berasal dari bahasa inggris inquiry yang dapat diartikan sebagai proses bertanya dan mencari tahu jawaban terhadap pertanyaan ilmiah yang diajukan. Inkuiri adalah suatu proses untuk memperoleh dan mendapatkan informasi dengan melakukan observasi atau eksperimen guna mencari jawaban maupun memecahkan masalah terhadap pertanyaan atau rumusan masalah dengan menggunakan kemampuan berfikir kritis dan logis (Trianto, 2007).

Pada penelitian ini, tahapan pembelajaran yang digunakan mengadaptasi dari tahapan pembelajaran inkuiri yang dikemukakan oleh Eggen \& Kauchak
(2007) dalam Trianto (2007). Tahapan model pembelajaran inkuiri dapat dilihat pada Tabel berikut.

Tabel 2. Sintaks Model Pembelajaran Inkuiri sebagai berikut:

\begin{tabular}{ll}
\hline \multicolumn{1}{c}{ Fase } & \multicolumn{1}{c}{ Perilaku Guru } \\
\hline $\begin{array}{l}\text { Menyajikan } \\
\text { pertanyaan atau } \\
\text { masalah }\end{array}$ & $\begin{array}{l}\text { Guru membimbing siswa } \\
\text { mengidentifikasi masalah dan } \\
\text { masalah dituliskan di papan } \\
\\
\end{array}$ \\
& $\begin{array}{l}\text { tulis. } \\
\text { Guru membagi siswa dalam } \\
\text { kelompok }\end{array}$
\end{tabular}

2. Membuat - Guru memberikan hipotesis kesempatan pada siswa untuk curah pendapat dalam membentuk hipotesis serta memberikan bimbingan.

- Guru membimbing siswa dalam menentukan hipotesis yang relevan dengan permasalahan dan memprioritaskan hipotesis mana yang menjadi hipotesis pendidikan

3. Merancang - Guru memberikan percobaan kesempatan pada siswa untuk menentukan langkah-langkah yang sesuai dengan hipotesis yang akan dilakukan.

- Guru membimbing siswa mengurutkan langkahlangkah percobaan.

4. Melakukan - Guru membimbing siswa percobaan mendapatkan informasi untuk melalui percobaan memperoleh informasi

5. Mengumpulkan - Guru membimbing siswa dan menganaisis menganalisis data.

data - Guru memberi kesempatan pada tiap kelompok untuk menyampaikan hasil pengolahan data yang terkumpul

6. Membuat - Guru membimbing siswa kesimpulan dalam membuat kesimpulan (Sumber: Trianto, 2007)

\section{B. Media Simulasi}

Media simulasi merupakan segala sesuatu yang dapat digunakan sebagai sumber infromasi dan komunikas, yang memegang peranan penting sebagai salah satu factor yang mempengaruhi kualitas keberhasilan pembelajaran (Perkins, 2006).

Finkelstein (dalam Fahrizal, 2005) (Suprijono, 2013), telah melakuka pengujian efek simulasi 
komputer sebagai pengganti laboratoriu nyata dalam pembelajaran fisika di kelas dan memperoleh hasil siswa yang di ajar melalui simulasi mendapatkan hasil belajar yang luar biasa dibandingkan dengan siswa yang diajar menggunakan laboratorium nyata.

\section{PhET}

PhET adalah sebuah software media pembelajaran yang di dalamnya terdapat beberapa materi simulasi pembelajaran fisika untuk kepentingan pengajaran dikelas atau dapat digunakan untuk kepentingan belajar individu (Setyosari, 2013).

\section{Sintaks Model Pembelajaan Inkuiri dengan Menggunakan Media Simulasi}

Sintaks model pembelajaran inkuiri dengan menggunakan media simulasi dapat dilihat pada tabel dibawah ini.

Tabel 3. Tahapan-tahapan model pembelajaran inkuiri dengan menggunakan media simulasi

Tahapan Perilaku guru $\quad$ Perilaku siswa

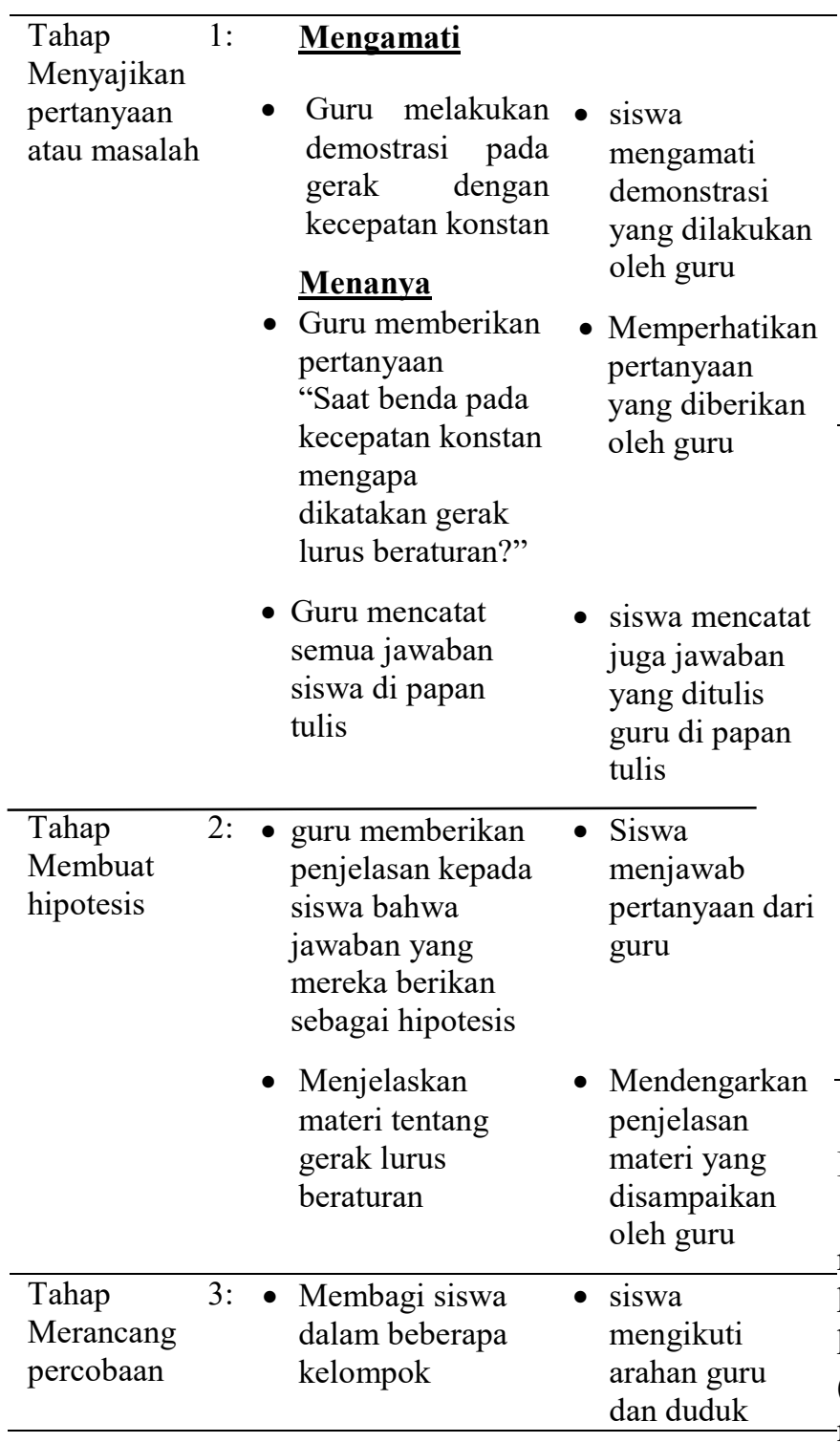

\begin{tabular}{|c|c|c|}
\hline & $\begin{array}{l}\text { - Membagikan } \\
\text { Lembar Kegiatan } \\
\text { Siswa (LKS) } \\
\\
\text { - Meminta siswa } \\
\text { melakukan } \\
\text { simulasi }\end{array}$ & $\begin{array}{l}\text { sesuai } \\
\text { kelompok } \\
\text { - Mengerjakan } \\
\text { LKS yang } \\
\text { sudah } \\
\text { dibagikan } \\
\text { - Berdiskusi } \\
\text { dengan } \\
\text { kelompok } \\
\text { dalam } \\
\text { bersimulasi }\end{array}$ \\
\hline $\begin{array}{l}\text { Tahap 4: } \\
\text { Melakukan } \\
\text { percobaan } \\
\text { untuk } \\
\text { memperoleh } \\
\text { informasi }\end{array}$ & $\begin{array}{l}\text { - Guru } \\
\text { membimbing } \\
\text { siswa melakukan } \\
\text { simulasi } \\
\text { - guru membimbing } \\
\text { siswa untuk } \\
\text { mengerjakan LKS } \\
\text { berdasarkan } \\
\text { simulasi }\end{array}$ & $\begin{array}{l}\text { - Berdiskusi dan } \\
\text { mengerjakan } \\
\text { LKS dengan } \\
\text { anggota } \\
\text { kelompok } \\
\text { sesuai waktu } \\
\text { yang } \\
\text { ditetapkan oleh } \\
\text { guru } \\
\text { - Siswa } \\
\text { mengikuti } \\
\text { arahan guru } \\
\text { untuk } \\
\text { melakukan } \\
\text { simulasi } \\
\text { - Siswa } \\
\text { mengikuti } \\
\text { arahan guru } \\
\text { untuk } \\
\text { mengerjakan } \\
\text { LKS } \\
\text { berdasarkan } \\
\text { simulasi }\end{array}$ \\
\hline \multirow[t]{2}{*}{$\begin{array}{l}\text { Tahap 5: } \\
\text { Mengumpulka } \\
\mathrm{n} \text { dan } \\
\text { menganalisis } \\
\text { data hipotesis }\end{array}$} & $\begin{array}{l}\text { - Guru meminta } \\
\text { salah satu } \\
\text { perwakilan } \\
\text { kelompok untuk } \\
\text { menyampaikan } \\
\text { hasil diskusi } \\
\text { media simulasi }\end{array}$ & $\begin{array}{l}\text { - Salah satu } \\
\text { kelompok } \\
\text { menyampaikan } \\
\text { hasil diskuasi } \\
\text { kelompoknya }\end{array}$ \\
\hline & $\begin{array}{l}\text { - Guru meminta } \\
\text { kelompok lain } \\
\text { menanggapi hasil } \\
\text { diskusi kelompok } \\
\text { yang maju }\end{array}$ & $\begin{array}{l}\text { - Kelompok lain } \\
\text { menanggapi } \\
\text { hasil diskusi } \\
\text { kelompok yang } \\
\text { maju }\end{array}$ \\
\hline $\begin{array}{l}\text { Tahap 6: } \\
\text { Membuat } \\
\text { kesimpulan }\end{array}$ & $\begin{array}{l}\text { Guru membimbing } \\
\text { siswa dalam } \\
\text { membuat } \\
\text { kesimpulan. }\end{array}$ & $\begin{array}{l}\text { Siswa membuat } \\
\text { kesimpulan } \\
\text { bersama guru }\end{array}$ \\
\hline
\end{tabular}

\section{E. Hasil Belajar Siswa}

Hasil belajar adalah pola-pola perbuatan, nilainilai, pengertian-pengertian, sikap-sikap, apresiasi dan kerampilan. Menurut Bloom, hasil belajar mencakup kemampuan kognitif, afektif dan psikomotorik (Herayanti \& Habibi. 2015). Domain kognitif mencakup knowledge (pengetahuan), comprehension 
(pemahaman), application (menerapkan), analysis (menguraikan), synthesis (mengorganisasikan), dan evalution( menilai).

\section{Metode Penelitian}

Penelitian termasuk penelitian eksperimen semu dimana pada penelitian eskperimen semu peneliti tidak memiliki keleluasaan memanipulasi subjek [14]. Desain penelitian menggunakan post-test control group design, data awal yang digunakan untuk mengetahui homogenitas kemampuan awal siswa yaitu dengan menggunakan nilai ulangan harian kedua kelompok sampel, kemudian kedua kelompok mendapatkan perlakuan yang berbeda yaitu kelompok eksperimen diberikan perlakuan berupa penerapan pembelajaran model pembelajaran inkuiri dengan metode eksperimen sedangkan bagi kelompok kontrol diberikan perlakuan dengan menerapkan pembelajaran konvensional di sekolah berupa pengajaran langsung, dan diakhiri dengan dilakukan tes akhir pada kedua sampel.

Teknik pengambilan sampel pada penelitian ini menggunakan purposive sampling dengan sampel seluruh kelas X MIA SMAN 1 LINGSAR. Analisis data hasil belajar fisika siswa akhir diawali dengan menguji prasyarat analisis yaitu uji homogenitas menggunakan uji varians atau uji-F dan uji normalitas menggunakan rumus uji chi kuadrat. Kemudian, analisis data hasil tes akhir uji hipotesis dalam penelitian ini menggunakan uji $t$-test polled varians [15].

\section{Hasil dan Pembahasan}

Hasil belajar yang diukur dalam penelitian ini adalah kemampuan kognitif siswa pada materi Gerak Lurus Beraturan dan Gerak Lurus Berubah Beraturan. Kemampuan penguasaan konsep siswa disajikan melalui data hasil tes akhir dalam Tabel 3.

Tabel 3. Data Tes Akhir Hasil Belajar Fisika Siswa

\begin{tabular}{lccccc}
\hline \multicolumn{1}{c}{ Kelas } & $\begin{array}{c}\text { Jumlah } \\
\text { Siswa }\end{array}$ & $\begin{array}{c}\text { Nilai } \\
\text { Terendah }\end{array}$ & $\begin{array}{c}\text { Nilai } \\
\text { Tertinggi }\end{array}$ & Rata-Rata & Varians \\
\hline Eksperimen & 25 & 45 & 90 & 68,4 & 126,5 \\
Kontrol & 24 & 40 & 85 & 58,75 & 130,97 \\
\hline
\end{tabular}

Pada Tabel 3 terlihat bahwa hasil belajar siswa pada saat tes akhir siswa berbeda. Peningkatan hasil tes akhir terjadi pada kelas kontrol dan kelas eskperimen, akan tetapi peningkatan lebih besar pada kelas eksperimen yang menggunakan model pembelajaran inkuiri dengan menggunakan media simulasi. Hasil analisis uji hipotesis pada taraf signifikansi $5 \%$ diperoleh $t_{\text {hitung }}=2,98$ lebih besar dari $\mathrm{t}_{\text {tabel }}=2,01$. Hal ini menunjukkan bahwa hasil belajar fisika siswa yang menggunakan model pembelajaran inkuiri dengan menggunakan media simulasi memberikan pengaruh lebih baik dibandingkan dengan model pembelajaran konvensional pada materi gerak lurus beraturan dan gerak lurus berubah beraturan.

Berdasarkan hasil pengamatan peneliti selama proses pembelajaran berlangsung, terlihat bahwa model pembelajaran inkuiri dengan menggunakan media simulasi yang diberikan pada kelas ekperimen membuat siswa lebih aktif dalam belajar dan meningkatkan hasil belajar fisika siswa. Penggunaan media simulasi pada model pembelajaran inkuiri ini sangat mendukung siswa dalam menemukan konsepkonsep pada materi gerak lurus berauran dan gerak lurus berubah beraturan. Hasil ini sesuai dengan hasil penelitian sebelumnya yang menunjukkan bahwa hasil belajar kognitif siswa mengalami peningkatan rata-rata serta terpenuhinya ketuntasan belajar siswa setelah diterapkannya model pembelajaran inkuiri
(Wijayatni et al, 2010). Penelitian lain juga menunjukkan bahwa penggunaan model pembelajaran inkuiri dengan menggunakan media simulasi dapat meningkatkan aktivitas dan hasil belajar fisika siswa (Yulian et al, 2015).

Model pembelajaran inkuiri dengan menggunakan media simulasi dalam penelitian ini telah dapat meningkatkan hasil belajar fisika siswa di tingkat SMA. Dalam penelitian lain (Harjono, dkk., 2015), pembelajaran berbasis inkuiri dengan menggunakan media tiga dimensi berpengaruh terhadap sikap ilmiah siswa. Penerapan pembelajaran berbasis inkuiri tersebut dilakukan melalui strategi kooperatif tipe STAD dan NHT. Siswa-siswa pada kelas STAD dan NHT dilatih rasa ingin tahu dan berpikir ke depan dengan membuat rumusan masalah dan hipotesis dalam Lembar Hasil Inkuiri Siswa. Kejujuran mereka diasah dengan melaksanakan eksperimen sesuai dengan prosedur yang ada pada lembar panduan inkuiri siswa, mengerjakan kuis dan menjawab pertanyaan oleh guru tanpa membuat kecurangan dengan menyontek maupun bertanya pada temannya. Kedisiplinan, mereka diajarkan agar dalam mengerjakan eksperimen diusahakan tepat waktu. Ketelitian mereka ditempa dengan melaksanakan percobaan seteliti mungkin sebelum data yang diperoleh diolah kemudian mengulangi lagi percobaan yang mereka lakukan. Skeptis mereka dilatih dengan tidak langsung percaya terhadap asumsi 
atau hipotesis yang mereka bangun namun harus dibuktikan terlebih dahulu melalui percobaan,mengumpulkan, dan menganalis data sertamemverifikasikan dengan literatur (Buku SakuKemagnetan Siswa). Keberanian dalam kebenaran dan objektivitas mereka dilatih ketika menulis data hasil penelitian sesuai dengan eksperimen walaupun berbeda dari hipotesis dan literatur yang ada. Pada dasarnya, semua indikator sikap ilmiah siswa terbina dengan serangkaian kegiatan eksperimen yang dilakukan mulai dari menyusun rumusan masalah sampai mendiskusikan permasalahan tersebut dengan teman kelompoknya dan menyimpulkan pendapat yang paling relevan sebagai suatu kesimpulan kelompoknya.

Model pembelajaran inkuiri tidak hanya mampu meningkatkan hasil belajar dan sikap ilmiah siswa, tetapi juga meningkatkan kemampuan berpikir kritis siswa di tingkat SMA. Penelitian Handriani, dkk. (2015) menyimpulkan bahwa terdapat pengaruh model pembelajaran inkuiri terstruktur dengan pendekatan saintifik terhadap kemampuan berpikir kritis dan hasil belajar fisika siswa kelas X SMAN 1 Gerung tahun pelajaran 2014/2015. Model pembelajaran inkuiri terstruktur (MPIT) dengan pendekatan saintifik lebih baik dibandingkan dengan model pembelajaran ekspositori. Dalam penelitian dimaksud diperoleh informasi yakni hasil pengujian hipotesis terhadap data post-test hasil belajar fisika siswa pada kelas eksperimen dan kelas kontrol dengan menggunakan uji-t menunjukkan bahwa adanya pengaruh MPIT dengan pendekatan saintifik terhadap hasil belajar fisika siswa. Selain itu dapat terlihat dari hasil post-test data hasil belajar fisika siswa pada kedua kelas menunjukkan bahwa nilai rata-rata kelas eksperimen lebih tinggi dibandingkan dengan kelas kontrol. Hal ini menunjukkan bahwa MPIT dengan pendekatan saintifik yang diterapkan pada kelas ekseprimen lebih baik dibandingkan dengan model pembelajaran ekspositori yang diterapkan pada kelas kontrol.

Lebih lanjut dikatakan bahwa MPIT dengan pendekatan saintifik sangat memposisikan siswa sebagai pusat dalam pembelajaran (student-centred), sehingga memberikan peluang pada peningkatan hasil belajar fisika. MPIT dengan pendekatan saintifik dapat memberikan peluang kepada siswa untuk berpartisipasi aktif dalam proses belajar. Siswa yang belajar untuk menemukan konsep pengetahuannya sendiri akan memperoleh pengalaman lebih bermakna dan pengetahuannya lebih kuat melekat dalam ingatan mereka. Dengan kuatnya informasi yang melekat pada memori siswa, tentu akan berdampak pula terhadap perolehan hasil belajar siswa. Sebaliknya pembelajaran ekspositori lebih menekankan kepada proses penyampaian materi secara verbal dari seorang guru kepada siswa agar siswa dapat menguasai materi pembelajaran secara optimal. Dalam penerapan model pembelajaran ekspositori pada kelas kontrol, siswa dijadikan sebagai penerima yang pasif dan hanya menghafal tanpa belajar untuk berpikir. Sehingga pengajaran bukanlah untuk menanamkan konsep tetapi lebih mengarah pada hafalan. Pada penelitian penerapan MPIT dengan pendekatan saintifik sangat memposisikan siswa sebagai pusat dalam pembelajaran (student-centred), sehingga memberikan peluang pada peningkatan hasil belajar. MPIT dengan pendekatan saintifik memiliki beberapa kelebihan dibandingkan dengan model pembelajaran ekspositori, diantaranya adalah siswa yang belajar melalui MPIT dengan pendekatan saintifik memiliki motivasi belajar yang lebih tinggi dibandingkan dengan siswa yang mengikuti pembelajaran ekspositori. Hal ini karena proses MPIT dengan pendekatan saintifik melatih siswa untuk aktif dalam proses pembelajaran dan siswa merasa senang ketika dilibatkan langsung dengan belajar, sedangkan siswa yang belajar dengan model pembelajaran ekspositori memiliki motivasi belajar yang rendah karena guru memposisiskan siswa sebagai penerima (siswa pasif) materi pelajaran dan proses pembelajaran dalam bentuk verbal. Selain itu MPIT dengan pendekatan saintifik dapat meningkatkan pemahaman siswa, karena pemahaman yang didapatkan melalui serangkaian proses belajar. Hal ini berdampak pada hasil belajar pada kelas eksperimen lebih baik dibandingkan dengan kelas kontrol.

Penelitian Kusdiastuti, dkk. (2016) menyimpulkan bahwa model pembelajaran inkuri berbantuan laboratorium virtual berpengaruh terhadap penguasaan konsep fisika siswa di tingkat SMA/MA. Data hasil penelitiannya menunjukkan bahwa rata-rata tes awal peserta didik pada kedua sampel sebesar 38,25 untuk kelas kontrol dan 39,04 untuk kelas eksperimen. Pada Tabel 1, menunjukkan bahwa kelas kontrol dan kelas eksperimen homogen yang berarti kedua kelas sampel memiliki kemampuan awal yang sama. Selain itu, hasil rata-rata tes awal yang rendah disebabkan karena kedua kelas belum memperoleh materi alat-alat optik sesuai dengan jenjang pendidikannya. Pengetahuan yang mereka miliki hanya berupa pengetahuan dasar tentang pemantulan dan pembiasan cahaya yang diperoleh di sekolah menengah pertama. Setelah dilakukan tes awal, selanjutnya kedua kelas sampel diberi perlakuan yang berbeda dan terakhir dilakukan tes akhir. Berdasarkan hasil tes akhir peserta didik terjadi peningkatan nilai rata-rata tes akhir dari nilai rata-rata tes awal. Jika dibandingkan peningkatan nilai rata-rata tes akhir kedua kelompok sampel, terlihat bahwa peserta didik kelas eksperimen dengan model pembelajaran inkuiri berbantuan laboratorium virtual menunjukkan peningkatan yang lebih tinggi daripada peserta didik kelas kontrol dengan pembelajaran konvensional. 
Peningkatan nilai rata-rata penguasaan konsep pada kelas eksperimen disebabkan karena tersedianya visualisasi konsep dengan bantuan laboratorium virtual yang disajikan pada setiap materi membuat peserta didik pada kelas eksperimen lebih mudah memahami materi yang dipelajari dibandingkan dengan kelas kontrol.

Selanjutnya hasil tes akhir juga digunakan untuk perhitungan uji homogenitas dan uji normalitas sehingga diperoleh bahwa kedua kelas setelah diberi perlakuan memiliki varians yang homogen dan terdistribusi normal. Setelah mengetahui homogenitas dan normalitas kedua kelas kemudian dilakukan uji hipotesis dengan taraf signifikan 5\% dimana diperoleh thitung $=3,897$ lebih besar dari tabel $=2,032$. Hal ini berarti terdapat perbedaan penguasaan konsep fisika menggunakan model pembelajaran inkuiri berbantuan laboratorium virtual dengan pembelajaran konvensional pada peserta didik MA DI Putri Nurul Hakim Kediri tahun pelajaran 2015/2016. Selain melakukan analisis pengujian hipotesis, peneliti juga ingin mengetahui peningkatan pada setiap aspek kognitif yang mengacu pada taksonomi Bloom. Indikator penguasaan konsep yang digunakan yaitu mengingat, memahami, menerapkan, menganalisis, mengsintesis dan mencipta. Atau dapat disimbolkan mulai dari $\mathrm{C} 1$ hingga $\mathrm{C} 6$. Persentase ranah kognitif tes awal peserta didik pada kedua kelas. pada tes awal kedua kelas ranah kognitif $\mathrm{C} 1$ (mengingat) lebih tinggi dari lima ranah lainnya yaitu 54\% untuk kelas kontrol dan $63 \%$ untuk kelas eksperimen. Hal ini dikarenakan, pengetahuan yang dimiliki hanya pengetahuan dasar yang diperoleh dari jenjang sebelumnya. Untuk ranah kognitif $\mathrm{C} 2$ hingga $\mathrm{C} 4$ kelas kontrol lebih tinggi dibandingkan dengan kelas eksperimen tetapi tidak terlalu signifikan, sedangkan ranah kognitif C5 dan C6 kelas eksperimen lebih tinggi dari kelas kontrol. Hal ini berarti sebaran ranah kognitif untuk kedua kelas cukup merata atau tidak telalu berbeda signifikan. Untuk ranah kognitif $\mathrm{C} 2$ hingga $\mathrm{C} 4$ kelas kontrol lebih tinggi dibandingkan dengan kelas eksperimen tetapi tidak terlalu signifikan, sedangkan ranah kognitif C5 dan C6 kelas eksperimen lebih tinggi dari kelas kontrol.

Lebih lanjut dijelaskan bahwa $\mathrm{Hal}$ ini berarti sebaran ranah kognitif untuk kedua kelas cukup merata atau tidak telalu berbeda signifikan. Berdasarkan Gambar 2, dapat diketahui bahwa pada tes akhir ranah kognitif dari C1 sampai C6 lebih tinggi daripada tes awal. Hal ini dikarenakan kedua kelas telah diberikan perlakuan. Selain hal diatas, peneliti ingin juga mengetahui sejauh mana peningkatan yang dialami kedua kelas secara lebih terperinci terkait hubungan nilai kelas kontrol dan kelas eksperimen untuk persentase kenaikan penguasaan konsep setiap sub materi. Materi optik dalam penelitian ini dibatasi pada konsep optik geometri yang secara garis besar dapat dikelompokkan menjadi 4 sub materi yaitu, cermin dan lensa, mata dan kacamata, kamera dan lup serta mikroskop dan teropong. Setiap sub materi dianalisis ketercapaiannya berdasarkan perolehan skor tes awal dan tes akhir dan gain ternormalisasi. Perbedaan peningkatan penguasaan konsep di setiap materi kedua kelas menunjukkan perbedaan tertinggi pada sub materi cermin dan lensa yaitu sebesar $81 \%$ pada kelas eksperimen dan $60 \%$ pada kelas kontrol. Hal ini berarti informasi yang diterima oleh peserta didik di kedua kelas sampel mengenai konsep cermin dan lensa cukup merata, selain itu sub materi cermin dan lensa merupakan materi awal dalam penyampaiannya dan materi ini juga merupakan materi yang pernah diajarkan ditingkat sebelumnya. Hal yang menarik pada sub materi mikroskop dan teropong, presentase kelas kontrol lebih besar 3\% dibandingkan dengan kelas eksperimen. Hal ini disebabkan karena beberapa faktor eksternal yang tidak bisa peneliti kontrol yaitu pada pertemuan keempat yang merupakan pertemuan terakhir dalam proses pembelajaran, sehingga pada fase- 8 (menarik kesimpulan) tidak bisa sepenuhnya dilaksanakan, hal ini terjadi karena mendekati jam istirahat. Selain itu, selama pembelajaran pada kelas eksperimen waktu lebih banyak terbuang pada fase-7 (menganalisis data) sehingga guru belum sempat memberikan latihan soal agar peserta didik lebih memahami materi mikroskop dan teropong.

Materi gerak lurus dalam penelitian model pembelajaran inkuiri dengan menggunakan media simulasi ini dibatasi pada 2 sub materi, yaitu gerak lurus beraturan dan gerak lurus berubah beraturan.

\section{PENUTUP}

Berdasarkan hasil penelitian, analisis data, serta pembahasan maka dapat disimpulkan bahwa terdapat pengaruh model pembelajaran inkuiri dengan menggunakan media simulasi terhadap hasil belajar fisika siswa kelas X MIA SMAN 1 Lingsar tahun pelajaran 2016/2017. Nilai rata-rata tes hasil belajar fisika kelas eksperimen yang menggunakan model pembelajaran inkuiri dengan menggunakan media simulasi lebih tinggi dibanding kelas kontrol yang menggunakan model pembelajaran konvensional.

\section{UCAPAN TERIMA KASIH}

Penulis menyampaikan ucapan terima kasih yang sebanyak-banyaknya kepada semua pihak yang turut serta membantu dalam penelitian ini, pihak sekolah SMAN 1 Lingsar serta untuk kedua dosen pembimbing hebat yang selalu sabar dan penuh semangat memberikan masukan dan sarannya, serta untuk teman-teman semua atas dukungan dan motivasinya. 


\section{REFERENSI}

Fahrizal, H. (2005). Media Sebagai Sumber Informasi dan Komunikasi. Jakarta: Salemba Empat.

Handriani, L. S., Harjono, A., Doyan, A. (2015). Pengaruh Model Pembelajaran Inkuiri Terstruktur Dengan Pendekatan Saintifik Terhadap Kemampuan Berpikir Kritis Dan Hasil Belajar Fisika Siswa. Jurnal Pendidikan Fisika dan Teknologi, 1(3), 210-220.

Harjono, A., Jufri, A. W., Arizona, K. (2015). Implementasi Media Tiga Dimensi Kemagnetan Berbasis Inkuiri Melalui Strategi Kooperatif Terhadap Sikap Ilmiah Siswa. Jurnal Pendidikan Fisika dan Teknologi, 1(1), 15-23.

Herayanti, L, dan Habibi. (2015). Model Pembelajaran Berbasis masalah Berbantuan Simulasi Komputer untuk Meningkatkan Keterampilan Berfikir Kritis Calon Guru Fisika". Jurnal pendidikan Fisika dan Teknologi Universitas Mataram, 1(1), 61-66.

Isa, A., Wahyudin, dan Sutikno. (2010). Keefektifan pembelajaran Berbantuan Multimedia menggunakan Metode Inkuiri Terbimbing untuk Meningkatkan Minat dan Pemahaman Siswa. Jurnal Pendidikan Fisika Indonesia 6: 58-62.

Jufri, W. (2010). Belajar dan Pembelajaran Sains. Mataram: Arga Puji Press.

Kusdiastuti, M., Harjono, A., Sahidu, H., Gunawan. (2016). Pengaruh Model Pembelajaran Inkuiri Berbantuan Laboratorium Virtual Terhadap Penguasaan Konsep Fisika Peserta Didik. Jurnal pendidikan Fisika dan Teknologi Universitas Mataram, 2(3), 116-122.

Perkins, Katherine. (2006). Phet: Interactive Simulasi for Teaching and Learning Physics. The Physics Teacher, 44(1), 303.

Rusman. (2010). Model-Model Pembelajaran. Bandung: Rajawali Pers.

Rusman. (2013). Belajar dan Pembelajaran Berbasis Komputer. Bandung: Alfabeta.

Setyosari, P. (2013). Metode penelitian dan pengembangan. Jakarta: kencana.

Suprijono, A. (2013). Cooperative Learning. Surabaya: Pustaka Pelajar.

Trianto. (2007). Model Pembelajaran Inovatif Berorientasi Konstruktivistik. Jakarta: Prestasi Pustaka.
Wijayatni, P.I., Mosik, Dan Hindarto, N. (2010). "Eksplorasi Kesulitan Belajar Siswa Pada Pokok Bahasan Cahay dan Upaya Peningkatan Hasil Belajar Melaui Pembelajaran Inkuiri Terbimbing". Jurnal Pendidikan Fisika Indonesia, 6(1), Hal 1-5.

Yulian, P.M., Suratno dan Aisyah, I.N. (2015). "Pengaruh Model Pembelajaran Inkuiri Terbimbing (Giuided Inquiry) dengan Menggunakan Metode Eksperimen terhadap Aktivitas dan Hasil Belajar IPA-Biologi Siswa Kelas VIII SMP Negeri 2 Maesan Bondowoso". Jurnal Pancaran, 4(2), 163-172. 